\title{
EL DIÁLOGO ENTRE PALABRA E IMAGEN EN EN EL CENTRO DE UN CÍRCULO DE ISLAS
}

Céline PEGORARI

Université Paul Valéry, Montpellier 3

Un signo, un solo signo en el muro del tiempo.

Andrés Sánchez Robayna La poesía es la primera respuesta frente a lo inconcebible que es la muerte.

Raúl Zurita

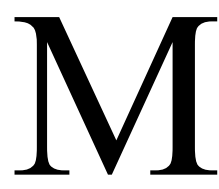
ás allá de la evocación de la peregrinación de un yo poético por las islas del mar Egeo hasta la isla de Delos en la que aspira a penetrar el misterio del universo, se puede considerar En el centro de un círculo de islas como una respuesta, por muy ilusoria y efímera que sea, a la inexorabilidad de la muerte y de la finitud que el poeta ha podido experimentar a lo largo de ese viaje y que se puede resumir con esos versos finales: «El vilano. Sólo tu sombra / pesa menos que tú / sobre la tierra. Aún menos que tu sombra, / nuestro paso en el polvo» (Sánchez Robayna, 2007: 63).

Aunque el soporte de la obra no deje de ser el papel, material igual de frágil y ligero que el vilano y aún más sometido a los estragos del tiempo que la piedra de los templos griegos omnipresentes en la obra, el gran esmero en hacer de En el centro de un círculo de islas un libroobjeto, tanto por la presencia de los dibujos del artista aragonés José Manuel Broto como por la calidad de la encuadernación artesanal y del papel utilizado, ilustra esa voluntad por parte del poeta canario de convertir la escritura en inscripción, «ya sea en el muro, sobre la piedra o en la página en blanco o lo que es lo mismo, "palabra-mineral”» (Fernández Casanova, 2005: 146), tal y como lo subrayaba Manuel Fernández Casanova en «...sentidos que no sé: el pensamiento poético de Andrés Sánchez Robayna».

«Esa piedra» que el poeta saca de las aguas y que presenta en «A. trae un nuevo y hermoso callao, en la luz que sonríe» como su «legado: pan eterno, belleza, jade fulvo» (Sánchez Robayna, 2007: 47) podría, de hecho, interpretarse como una alusión a la obra que nos ofrece el poeta canario. Semejante interpretación puede justificarse por la importante dimensión autorreflexiva del conjunto de la obra de la que participa el diálogo entre palabra e imagen. Los nueve dibujos de José Manuel 
Broto contribuyen, a nuestro parecer, a la mise en abyme del proceso de creación poética por el intercambio con las palabras, pero sobre todo por los parecidos y las diferencias con ellas a la hora no sólo de «hacer visible» sino de «ser visible» tal como definía Klee el arte moderno. En esa materialidad de la obra a la que contribuyen los dibujos se afirma el ser según las modalidades que vamos a analizar, después de un breve repaso a la relación entre palabra y pintura en el pensamiento y la obra del poeta canario.

\section{Imaginación poética e imaginación plástica}

«Desde mis inicios en la escritura, hacia 1970 -y aun antes-, poesía y artes plásticas han estado para mí muy unidas y recuerdo que en 1969 escribí y publiqué un poema a una pintura de Joan Miró. La imaginación poética ha estado para mí aliada en todo momento a la imaginación plástica» (Eusebio, 2015: 53). Con estas palabras evocaba Andrés Sánchez Robayna su interés por la pintura en una entrevista de junio de 2015 en Cuadernos Hispanoamericanos. Además de haber publicado numerosos escritos sobre artes plásticas y fotografía, recogidos en sus libros de ensayo como La luz negra o Deseo, imagen, lugar de la palabra, y también Variaciones sobre el vaso de agua, el poeta canario ha colaborado, como lo recuerda en esa misma entrevista, «con artistas plásticos como Tàpies, Broto, Sicilia o Palmero en distintos libros y proyectos» (Eusebio, 2015: 53). Con ello se refiere a los poemarios Sobre una confidencia del mar griego, precedido de Correspondencias (2005), En el centro de un círculo de islas (2007), Reflejos en el día de año nuevo (2008), así como a la colaboración en revistas. Habría que añadir las obras que no hemos podido consultar y cuya lista hemos podido ver en la bibliografía del monográfico de Poesía en el campus dedicado en 1995 a Andrés Sánchez Robayna. Se trata, entre otras, de «El resplandor», «Lugar», «La retama»y «Obediencia, el volcán».

Si el interés de los poetas por la pintura no es nada nuevo, como tampoco lo es la relación entre pintura y poesía ${ }^{1}$, cabe precisar que, por muy paradójico que pueda parecer, no es la capacidad de representación de la pintura lo que le parece interesar a Sánchez Robayna. Se puede, en efecto, deducir de sus diferentes escritos sobre pintura que lo que destaca es la dimensión lírica de la misma. Subraya, en efecto, «el exultante lirismo» de la obra de José Manuel Broto (Sánchez Robayna, 2007: 70) y la «explosión lírica» que se da en la de Vicente Rojo (Sánchez Robayna, 2008: 254). Se ve que ese lirismo aparece vinculado con lo espiritual. Esa «explosión lírica» de la que habla a propósito de Rojo puede relacionarse, en efecto, con la «creciente espiritualización de la forma» evocada en el mencionado artículo que ha podido observar el poeta en la obra del mexicano (Sánchez Robayna, 2008: 259). Ese vínculo es todavía más explícito en el caso de las reflexiones acerca de la producción artística de José Manuel Broto. Remitiendo a la exposición de homenaje a san Juan de la Cruz que tuvo lugar en Sevilla en 1991, y en la que participaron José María Sicilia y José Manuel Broto,

\footnotetext{
${ }^{1}$ Recuerda Andrés Sánchez Robayna en una entrevista publicada en Cuadernos Hispanoamericanos que pintura y poesía van íntimamente ligadas desde la célebre definición de Simónides de Ceos «la poesía como pintura que habla y la pintura como poesía muda» así como del famoso «Ut pictura poesis horaciano» (Eusebio, 2015: 53).
} 
destaca Andrés Sánchez Robayna que si se podía relacionar la obra de Sicilia con el universo lírico del poeta místico por «la radicalidad y la extremosidad de su aventura artística, en el caso del artista aragonés era por «el sentido marcadamente espiritualista y contemplativo de su obra» (Sánchez Robayna, 2008: 288). Esa característica es la que resalta en el artículo que le dedica en 1998 y que figura al final de En el centro de un círculo de islas. Insistiendo en el papel de Kandinsky a la hora de destacar la «dimensión espiritual de la experiencia artística» (Sánchez Robayna, 2007: 70), el poeta afirma que es ésta la que da Broto a su obra, antes de añadir que «no causa ninguna sorpresa, para quien se haya acercado alguna vez a la obra del pintor aragonés, identificar aquí con toda claridad el testimonio de una experiencia contemplativa» (Sánchez Robayna, 2007: 70)². Precisa, como lo veremos más detenidamente en los dibujos que acompañan los poemas de Sánchez Robayna en En el centro de un círculo de islas, que

\begin{abstract}
[...] los "signos" encontrados en la aventura plástica y su presencia en la tela son el fruto de una visión que ha sabido fijar las imágenes como un acto de espíritu. La de Broto es una experiencia siempre retiniana, sin duda, pero propone siempre, del mismo modo, un más adentro (entremos más adentro en la espesura), un ojo adentro: no sólo ver, se diría, sino contemplar. De ahí que uno de sus críticos, Olivier Kaeppelin, haya escrito a propósito de Broto que estamos ante una fuerza pictórica "no sólo perceptiva, sino filosófica y práctica en su capacidad de hacer sentir la presencia de lo sagrado en la experiencia del ser" (Sánchez Robayna, 2007: 70).
\end{abstract}

Es lo que recalca también de la obra de Frederic Amat y de la de Antoni Tàpies. Subraya en los cuadros de esos artistas catalanes la importancia de la materia en esta presencia de lo sagrado. Si remite a la «ceremonia» que surge de los «cruzamientos de lo visible y lo invisible» en la pintura de Frederic Amat, la «experiencia de lo sagrado» que se da en la de Antoni Tàpies se aprecia en la materialidad de la misma ${ }^{3}$. Recuerda, en efecto, que «lejos de proponer una experiencia de lo sagrado como secessio del mundo exclusivamente orientada hacia el espíritu», Tàpies muestra «la inanidad de una visión del espíritu al margen de la materia»:

Materia y espíritu no serían sino formas de una sola y única realidad. De ahí que la letra y la escritura, en su materialidad -y sólo en su materialidad-, hayan sido vías de acceso a un conocimiento que permite percibir espíritu y materia como mundos no separados, como no-dualidad (Sánchez Robayna, 2008: 227).

Esta presencia de lo espiritual, de lo sagrado en la materia caracteriza también la obra poética de Andrés Sánchez Robayna. Se puede interpretar como el intento de hacer visible, de plasmar mediante la escritura lo invisible, el misterio que intuye el poeta en un más allá de las apariencias.

\footnotetext{
${ }^{2}$ Lo que confirma Broto afirmando a propósito de la serie Botánica que es «un pintor abstracto y estas series ofrecen una condensación sintética muy apropiada que tiene más relación con la música y la poesía» (Broto, 2005: 26).

${ }^{3}$ Hace también hincapié Andrés Sánchez Robayna en la presencia de lo sagrado en la materialidad en la obra de los artistas anteriormente evocados, como por ejemplo José María Sicilia y su trabajo sobre la cera (Sánchez Robayna, 2008: 285) y Frederic Amat, cuya obra entera presenta como un «viaje a la materia»: «El de Amat también es siempre, claro está, un viaje a la materia. Quizá es ése el viaje de los viajes, el viaje que da lugar a todos los demás, el viaje primigenio» (Sánchez Robayna, 2008: 279). Añade: «Si la materia es siempre en esta obra el centro de la visión y de la celebración ceremonial, éstas encuentran en el objeto lo que podríamos llamar su eidos, su principio y su fin -su fin que es su principio».
} 
Como lo resume el profesor Túa Blesa en su reseña de La sombra y la apariencia, el fundamento de esta obra radica en

[...] la intuición de que más allá de lo visible, de lo perceptible en general, hay otra realidad, una realidad esquiva, que se oculta. [...] Aunque en ocasiones se revela como un fulgor, como el instante de la iluminación de un relámpago -la experiencia poética que se vincula con lo sagrado-, y decirla sería el cometido que la escritura debería cumplir. De lo que se trata, es desvelar ese algo más, ese mundo que late tras el mundo real (Blesa, 2010).

No es de extrañar que el poeta declare a propósito de las demás artes que «la escultura o la pintura o la música que más [le] conmueven son aquellas que, como la poesía, aparecen como llevadas por una especie de sentimiento litúrgico, un sentimiento intuitivo» (Díaz, 1995: 6) que nace de ese encuentro, de «esa ceremonia» entre materialidad y espiritualidad. La dualidad intrínseca del signo lingüístico contribuye a que se produzca ese encuentro en la creación poética: aunque en numerosas ocasiones ha destacado el poeta la materialidad de ese signo, tanto por ser un dibujo en la página como por su dimensión fónica ${ }^{4}$, reconoce en el artículo dedicado a José María Sicilia que «la materialidad del lenguaje no es sino la mitad de la palabra; su otra mitad es evanescente, fantasmal, huidiza» (Sánchez Robayna, 2008: 284). Remite con ello a la «irrenunciable componente semántica que introduce en ella, casi de manera fantasmal, la abstracción y la ausencia» (2008: 283). La poesía es lo que parece permitir volver a unir esos dos componentes del signo lingüístico, tal y como Andrés Sánchez Robayna lo evocaba acerca del motivo del vaso de agua en Variaciones sobre el vaso de $a g u a^{5}$, y sobre todo relacionarlo con el mundo. No se trata, como en el caso de Mallarmé, de 'remotivar' mediante la poesía el vínculo entre significante y significado sino de revelar «el misterio esencial de la materia» tal y como explica en «Deseo, imagen, lugar de la palabra»:

La iluminación de la poesía se da en la palabra, como si la carnalidad de la palabra fuera del todo imprescindible para acceder a un conocimiento otro, a lo que he llamado el conocimiento de lo impensable. Pero es esa carnalidad, esa materialidad, lo que nos permite recordar en todo momento la propia materia del mundo; lo que hace posible, por otra parte, que la palabra no se pierda en los pliegues de una extrema idealidad, esto es, en un mundo de abstracciones, de figuras o de imágenes plenamente alejadas ya de lo que constituye una buena parte del impulso primigenio de lo poético que no es otro que el hechizo de la fisicalidad del mundo. La palabra es, sí, expresión o metáfora de la fisicalidad, como si los juegos de la phoné en los que la poesía gusta demorarse [...] consistieran sobre todo en hacernos ver el misterio esencial de la materia (Sánchez Robayna, 2008: 348).

La poesía no parece tener así otro fin que el de experimentar ese misterio esencial de la 'fisicalidad' del mundo a través de la de la palabra. Es lo que dice Haroldo de Campos a propósito del poemario Tinta citado por Ana Mata Buil en su estudio sobre el poema en prosa de Andrés Sánchez Robayna:

\footnotetext{
${ }^{4}$ «En su ensayo “La 'materialización’ de la poesía” (1974), el pintor [Antoni Tàpies] ha recordado oportunamente que la letra "ha sido primero dibujo, y la palabra, antes de convertirse en un grupo de signos abstractos, ha sido también imagen plástica"» (Sánchez Robayna, 2008: 215).

5 «En los testimonios que nos ofrece, la poesía consiste precisamente en la impugnación de todo dualismo, en la instauración del principio de no dualidad, en la cerrada unidad de cuerpo y alma, de vaso y agua, de materia y espíritu. Unidad de sentido... Pero ¿es sentido, en realidad, lo que buscamos? Como en toda imagen, no se trata de desentrañar su sentido, sino de habitar su misterio» (Sánchez Robayna, 2015: 15).
} 
[...] la obra es también parte integrante de la realidad, de ahí que al mismo tiempo que el mundo escribe el poema, el poema escribe al mundo, y de algún modo lo complete, generándose así la unidad de texto y mundo, de la mirada y lo mirado, de todos los elementos de la realidad (Mata Buil, 2014: 725).

Sería, sin embargo, un error resumir la materialidad de la palabra en su dimensión física y fónica sin tener en cuenta el papel que tienen en ello las imágenes. En numerosas ocasiones se ha utilizado la facultad de crear imágenes de la poesía como prueba de su semejanza con las artes plásticas, en especial con la pintura. Andrés Sánchez Robayna afirma al respecto que «las imágenes poéticas hablan, pero lo hacen de manera distinta a las imágenes pictóricas» (Sánchez Robayna, 2015: 9). Se puede explicar esta diferencia por el proceso mental que supone la lectura de unas y otras. Se suele remitir, en efecto, a la inmediatez de la imagen pictórica mientras que el lector tiene que asociar el significante con un significado y conectarlo con el significado de otras palabras para poder acceder a la imagen poética. Esto no quita, sobre todo en el caso del arte abstracto, que la imagen pictórica sea igual de doble, a la vez material e inmaterial, física y abstracta, visible e invisible que la imagen poética, aunque parece predominar la dimensión material en las artes plásticas y la abstracción en la literatura. Con estas similitudes y diferencias parece jugar el poeta a la hora de componer la obra que aquí nos interesa. Se trata, en efecto, mediante la imagen y la palabra de construir esa unidad entre lo visible y lo invisible, lo material y lo inmaterial, lo interior y lo exterior, la luz y la sombra, lo temporal y lo eterno a que parece aspirar el yo poético que emprende ese viaje al «centro de un círculo de islas».

\section{Viaje al origen de la materia}

Los dibujos de José Manuel Broto destacan a la hora de descubrir el poemario por la inmediatez, antes evocada, de la lectura del signo icónico en comparación con el signo lingüístico. Aunque sean menos numerosos que los poemas y la primera imagen solo figure después de una larga cita de los Carnets de Camus y un primer poema titulado «Exordio», la presencia de estos dibujos ofrece al lector un doble acercamiento a la obra: puede elegir pasar de un dibujo a otro antes de emprender la lectura de los poemas, o seguir el orden establecido por el poeta y el artista a la hora de 'construir' el conjunto ${ }^{6}$. Sea cual sea su elección, la primera ilustración condiciona la lectura posterior del o de los poemas. Esta doble espiral en tonos grises que sobresale del folio en blanco llama la atención del lector por el contraste con los poemas que la preceden. Contrastan, en efecto, esos tonos con la evocación de los colores en la cita de Camus que alude a una puesta de sol en las islas Cícladas que sirve de marco al tercer volumen de sus Carnets. El gris claro con algún que otro toque de gris oscuro poco tiene que ver con ese «oro apagado», ese «verde malva», esos «colores» aunque se oscurezcan, ese «mar brillante» o ese «azul oscuro» en los que se vuelven «las masas de las islas» (Sánchez Robayna, 2007: 11). Además el sosiego evocado tanto en esta cita como en los versos de «Exordio», en este caso con la referencia a «una calma [que] se adueña, cuerpo mío, de ti»

\footnotetext{
${ }^{6}$ La elección del verbo construir en vez de componer no es fortuita como lo vamos a demostrar en esta segunda parte del artículo.
} 
(Sánchez Robayna, 2007: 13), no es precisamente lo que se desprende de esta espiral que se aprecia en el dibujo de José Manuel Broto.

Más allá de esta impresión de desfase inicial entre texto e imagen, el dibujo, tanto por no ser figurativo como por los colores utilizados, no deja de ser significativo del conjunto de la obra y de esa aspiración del yo poético a acceder a un misterio más allá de las apariencias sensibles. Parece reflejar la voluntad del poeta de alcanzar la esencia de las cosas y evocarlas en su obra desde esta esencia, este centro: una realidad en blanco y negro. Conviene añadir a todo ello que la técnica aparentemente empleada por el artista aragonés tiende a romper con la materialidad del dibujo: en efecto, parece que José Manuel Broto haya vuelto a recurrir al ordenador a la hora de componer las ilustraciones que figuran en En el centro de un círculo de islas. Tal y como lo subraya Gloria Collado a propósito de la serie Botánica:

[...] en esas formas «inmateriales» se produce un efecto contrario al que proyectan las formas pictóricas. El rastro acuoso de la pintura sobre el lienzo es una imagen que está tan estrechamente unida a la materia que hace imposible desligarla de ella (Collado, 2006: 11).

Precisa, sin embargo, unas líneas más abajo que

[...] las imágenes de ordenador son ya en su inmaterialidad una nueva realidad y desde esa realidad, se insinúan como algo orgánico, con una viscosidad lumínica que invita a imaginar mundos sumergidos, fondos marinos donde habitan las algas como otras formas de vida. Son imágenes estáticas, pero sabemos que la herramienta que las ha creado puede también ponerlas en movimiento, imágenes de síntesis las llaman [...] (Collado, 2006: 11).

$\mathrm{Al}$ crear «formas 'inmateriales'» (Collado, 2006: 11) que constituyen una nueva realidad desde la pantalla luminosa de un ordenador a partir de algoritmos computacionales, el artista plástico no parece hacer sino lo que pretende hacer el poeta con la palabra una vez haya llegado a ese «ciego origen de la luz» que «cifras / y nos cifra» (Sánchez Robayna, 2007: 38). Se trata de transmitirlo con los medios propios a cada uno. Consciente de las dificultades que tiene la palabra a la hora de comunicar el misterio del origen que intuye, el poeta intenta compensar esas limitaciones del logos mediante otros aspectos de la palabra que no sea su significado: pueden ser juegos en cuanto a la disposición de la palabra en la página, como en el caso de algunos poemas de Clima o Tinta, o con sus valores sensoriales y fónicos. El poeta ha aludido en numerosas ocasiones a la importancia de la dimensión fónica de la palabra, lo que vuelve a relacionar la poesía con la música, artes ligadas desde el origen de la palabra como de la creación poética. El poeta ha destacado la importancia de la música en su poesía y el parecido entre estas dos artes, como por ejemplo en una entrevista concedida a R.-F. Díaz:

La presencia de la música en estos nuevos poemas espero que no sea menos intensa de lo que siempre lo ha sido en todo lo que he escrito, es decir $-\mathrm{y}$ usted ya lo sabe - : una presencia fundamental. No concibo la palabra de la poesía si esa palabra no se configura, también, como una realidad sonora, una realidad que se hace presente, y presencia, gracias precisamente a su tersura musical. Esa es, además una de las verdades de la poesía. Tanto lo he creído siempre, que en alguna ocasión he visto la poesía como una fusión de mito y música, en fin, como la cristalización, la materialización sonora de esa verdad (Díaz, 1995: 7). 
Se puede apreciar esta dimensión en la obra que nos interesa aquí. Amén de las numerosas asonancias y aliteraciones, cabe destacar la importancia concedida al ritmo. Pruebas de ello, las numerosas anáforas o repeticiones, presentes en la obra, como por ejemplo en «Lo abierto» con la de «donde» (Sánchez Robayna, 2007: 19) al principio del verso de cada estrofa. Pero este ritmo, este latido del poemario, se da también en la alternancia entre poema e imagen así como en las correspondencias y las diferencias entre unos y otros. Se puede establecer un paralelismo con Sobre una confidencia del mar griego para la que el poeta canario colaboró con el artista Antoni Tàpies. Candelas Gala recurre al término 'contrapunto', término prestado de la música, para hablar de la relación que se da entre los signos iconográficos y los lingüísticos en esa obra (Gala, 2014: 433). Contribuye, según la profesora, a la polifonía del conjunto que, en el caso de En el centro de un círculo de islas, se manifiesta también en la serie de dualidades antes evocadas y que no son sino variaciones a partir de la oposición entre visible e invisible aunque tanto la escritura como los dibujos y la importancia concedida a la organización arquitectónica del conjunto contribuyen a reducirla. Este paso de la dualidad a la unidad es simbolizada por este viaje al centro que efectúa el yo poético y que no es sino una metáfora de la creación tanto poética como artística: un viaje a lo sagrado del que participan los dibujos de José Manuel Broto.

Aunque éstas no son ilustraciones en el sentido tradicional de la palabra, resultan de la lectura por parte del artista aragonés de los poemas de su amigo Andrés Sánchez Robayna tal y como se puede leer en la nota final del poemario ${ }^{7}$. Se tiene que considerar En el centro de un círculo de islas como un «libro de diálogo» tal y como define Yves Peyré el tipo de obras que nacen de la colaboración entre un poeta y un pintor, como la de Charles Cros y Mallarmé considerados como los autores, en 1876, del primer ejemplar de este tipo de obras:

De lui-même, positivement, le livre de dialogue est avant tout un désir partagé : il est le frémissement à l'unisson de deux créateurs avides de se rejoindre. Entre ces deux hommes, -le poète et le peintre-, il doit y avoir rencontre, accord, confrontation (Peyré, 2001: 59).

Este encuentro no significa que las imágenes remitan, como en el caso de la ilustración, a los elementos figurativos del poema en la medida en que las palabras desempeñan ya este papel, sino que hacen visible lo que piensa el artista que la palabra sugiere. Como lo afirma el teórico francés:

[...] tout livre de dialogue naît moins de l'envie de donner à la parole une assise de clarté [...] que de vérifier les ressources propres à la parole en la confrontant à son autre, à son tout-autre qui, au plus profond, est son tout-proche (Peyré, 2001: 42)

Es lo que destaca también Lisa Sabournin en la introducción del imprescindible Poésie et illustration dándole un sentido más novedoso a la ilustración:

\footnotetext{
7 «Este cuaderno de poemas y dibujos nació, de un modo natural y hasta diría que con fatalidad, al calor de una vieja amistad y del diálogo entre la palabra y la pintura» (Sánchez Robayna, 2007: 73).
} 
Illustrer, c'est souvent donner à comprendre sous l'angle d'une autre esthétique ce que le poème porte en soi, le révélateur iconique ou auditif décryptant les beautés secrètes du texte, permettant d'en mieux saisir l'architecture interne (Sabournin, 2008: 9).

Es esta definición de la ilustración la que caracteriza la colaboración de los dos $\operatorname{artistas}^{8}$. Las imágenes de Broto tienen que considerarse, en efecto, como interpretaciones del sentido profundo de los poemas por el artista, aunque no se trata tanto de desentrañar ese sentido como de vivirlo, de «habitarlo»9.

Lo hace el pintor aragonés mediante una serie de motivos abstractos. Algunos son formas concretas y/o geométricas que remiten a elementos presentes en el poema. Se trata del círculo anterior al poema en prosa que empieza por «CERO, ORIGEN, turbión o remolino, interminable círculo [...]» (Sánchez Robayna, 2007: 23) y del dibujo que precede a «Ierí Limni» en el que se puede apreciar una forma orgánica que recuerda la de unas algas, acorde con el marco marino del poemario. La forma enigmática que precede «De una danza» podría remitir, aunque de manera muy estilizada, al movimiento de una persona bailando como si de un cuadro futurista se tratara. Lo mismo pasa con el dibujo anterior a «Al dios de Delos» que nos recuerda al personaje caminando de la famosa escultura del artista futurista Boccioni. Aunque no podamos afirmar cualquier influencia de ese movimiento artístico en la obra de José Manuel Broto, cabe subrayar el parecido en cuanto a la manera de plasmar en el papel el movimiento tal y como intentaron hacerlo los futuristas, tan obsesionados por la velocidad del mundo moderno. En los dibujos del artista aragonés se trata más bien de aportar vida a lo que parecen ser formas estáticas mediante el ligero desfase en la superposición de la misma forma en distintas capas de tonos de grises. Amén de recordar el viaje del yo poético al centro hacia el que avanza pero que avanza igualmente hacia él («[...] fieles avanzamos / hacia ti, pero tú / avanzas igualmente hacia nosotros») (Sánchez Robayna, 2007: 38), puede remitir a este movimiento, esta vida que el poeta presiente en las cosas como esos «átomos bullentes / de lo eterno» (2007: 53) de la piedra en «Díptico de la piedra». No se trata pues de reproducir en estas imágenes lo que se pueda observar exteriormente sino, como en el caso del poeta, lo que se pueda intuir por debajo de las apariencias. En este sentido se deben interpretar las dobles espirales que se pueden contemplar en dos ocasiones, aunque presenten algunas diferencias. Además del hecho de plasmar el movimiento y remitir a la «espiral» del «ojo del tiempo» (Sánchez Robayna, 2007: 23) del poema «CERO, ORIGEN», esas dobles espirales recuerdan la doble hélice con la que se representa el ADN, origen de toda vida. Este parecido puede ser fortuito pero no deja de ser interesante en un poemario en el que la peregrinación hacia Delos no parece ser sino un viaje al origen del universo, de la existencia tal y como lo vamos a ver más detenidamente en la última parte del presente artículo.

\footnotetext{
${ }^{8}$ Es lo que destacaba ya Alejandro Rodríguez Refojo, en Letras Libres, a propósito de Sobre una confidencia del mar griego: «El pintor no aspira a representar las palabras, a recrear, con los medios que le son propios, esa realidad modelizada que, según Lotman, es el poema (el texto artístico en general), sino que pretende entablar un diálogo con él, en lo que puede ser considerado un verdadero ejercicio de "traducción intersemiótica", esto es, entre lenguajes diferentes» (Rodríguez-Refojo, 2006).

${ }^{9}$ Con ello parafraseamos la cita de Andrés Sánchez Robayna en Variaciones sobre el vaso de agua a propósito de la imagen poética: «Unidad de sentido... Pero ¿es sentido, en realidad, lo que buscamos? Como en toda imagen, no se trata de desentrañar su sentido, sino de habitar su misterio» (Sánchez Robayna, 2015: 15).
} 
Como en los poemas, los dibujos hacen visibles lo que no lo es, y que no es sino el misterio que se esconde debajo de las apariencias sensibles que el poeta intuye. Los juegos con las sombras y las luces, omnipresentes en los poemas ${ }^{10}$, parecen ser el medio elegido por el artista para dar a ver lo invisible. Las distintas capas superpuestas en tonos grises dan la impresión de que el artista está desvelando este invisible por el juego de contraste entre el gris claro tirando a beige, y el gris oscuro que se asemeja al negro. Estas superposiciones aportan, en efecto, profundidad a los motivos que parecen así surgir de la página en blanco. Resulta, sin embargo, difícil determinar si las formas más claras salen de las más oscuras o al contrario. Esta indeterminación es reveladora de un cuestionamiento general por parte del artista y del poeta en cuanto a lo real. En efecto, es éste lo visible, lo material que aparece plasmado mediante formas oscuras o son las siluetas claras, casi imperceptibles, que surgen de ellas. La confusión en cuanto a cuáles son las capas de abajo y las de arriba puede escenificar la interrogación en cuanto a si lo inmaterial, lo espiritual nace de la materia o si es la materia la que nace de lo inmaterial. Los poemas que acompañan los dibujos parecen dilucidar esta duda en cuanto es lo trascendente, lo sagrado y lo inmaterial lo que es el origen de la vida y de la materia. Es mediante la materia como el artista puede entonces acceder a ella en la medida en que son indisociables, como se puede deducir de los versos siguientes de «Lo abierto»: «Donde / el cuerpo está, / dices convocación, / sol absoluto» (Sánchez Robayna, 2007: 19). Es significativa al respecto la concepción que tiene Andrés Sánchez Robayna de lo trascendente «nunca entendido en clave de sublimación de la realidad, sino desde una actitud de mayor compromiso con la misma» (Fernández Casanova, 2005: 27).

Por ser síntesis del blanco y el negro, el color gris bien puede simbolizar esta unidad entre materia (lo oscuro, lo negro) y abstracción, invisibilidad (la luz) a la que aspira el poeta y que se manifiesta, como lo vamos a ver en la última parte de nuestro artículo, en la composición del poemario. La presencia de las ilustraciones de Broto tiene que considerarse, a nuestro parecer, como un medio a la hora de conseguir esa unidad. Aunque en estas están presentes las dualidades antes evocadas, y por mucho que el artista aspire a comunicar lo intangible y a lo invisible, la creación plástica, sobre todo por oposición con la escritura, es ante todo materia. Es lo que destaca Yves Peyré a propósito del «libro de diálogo» y que puede aplicarse perfectamente en el caso de En el centro de un círculo de islas:

Il y a dans l'œuvre d'art, malgré les arrière-plans infinis et le jeu de leurres que l'on a tôt fait d'y déceler, une évidence de matérialité, une proximité à première vue heureuse avec le monde (y compris lorsque le cri ou le sanglot sont le soubassement de l'acte), bref tout ce qui relève du visible se présente au spectateur comme une preuve du tangible. L'écriture, elle, qu'elle soit prose ou poésie, -et, si elle est poésie c'est encore plus vrai-, a rapport avec l'impalpable. Une page se regarde, elle ne se néglige pas d'avoir un

\footnotetext{
${ }^{10}$ Bien podrían aplicarse a En el centro de un círculo de islas estas palabras de Juan Antonio Masoliver Ródenas acerca de La roca: «El blanco y el negro son, pues, los colores dominantes, los más cercanos al silencio y a la música»; «Luz y colores que subrayan por lo tanto la materialidad de los objetos y del lenguaje, sus perspectivas, su plasticidad» (Masoliver Ródenas, 1995: 17). Aunque el blanco y el negro pueden remitir a ciertas características físicas, reales como por ejemplo la cal de las casas griegas y la oscuridad de la noche, como ese intermedio que es el gris de la sombra, conviene considerarlos más bien como parte de este proceso de esencialización por parte del poeta.
} 
côté dessin mais elle se lit (en silence, à voix haute), et là, ce n'est plus le visible qui prédomine, c'est le son (la poésie est assurément une forme exacerbée de musique) (Peyré, 2001: 12).

El poeta parece utilizar, en efecto, la materialidad de los dibujos como contrapunto a la inmaterialidad de la poesía, sobre todo en una obra en la que no hay juegos particulares, a diferencia de otros poemarios, en cuanto a la materialidad de la palabra escrita. La presencia de estos dibujos le da una mayor visibilidad y estabilidad al conjunto, lo que no deja de ser significativo en un poemario en el que se transcribe una peregrinación a Delos cuyo significado en griego, Dílos, no es sino estable y visible.

Cabe preguntarse si este intento de aferrarse a la materia, a lo visible, aunque sea en un principio para dar a ver el misterio del origen, no es una manera para el poeta de aferrarse a lo concreto, lo estable como si de una piedra, elemento omnipresente en el conjunto de la obra del poeta canario, se tratara. Prueba de ello, nos parece, es el gran esmero por parte de Andrés Sánchez Robayna a la hora de concebir la arquitectura de En el centro de un círculo de islas en el que poemas y dibujos participan tanto de la evocación del viaje del yo poético a Delos como de la mise en abyme del proceso de creación en el que el poeta se convierte en el Creador de este mundo de papel.

\section{La afirmación del ser en En el centro de un círculo de islas}

No deja de ser llamativa la importancia que tiene la geometría y el equilibrio en el conjunto de la obra, como se puede deducir del título mismo. Es cierto que semejante afirmación podría aplicarse a la mayoría de las obras de Andrés Sánchez Robayna. El poeta canario declaraba a propósito de Sobre una piedra extrema:

No concibo el libro como un mero "conjunto" de poemas, es decir, una pura actuación sobre lo acumulativo, y sobre la escritura diseminada en el tiempo. En mi caso se trata de algo más complejo, que atañe a una física del libro, que sueña con su «unidad», casi siempre imposible, pero que procede por un mecanismo de ilusión constructiva, casi arquitectónica. De ahí que yo mismo tenga a veces la impresión de estar presentando en cada libro, más que una reunión de poemas, un largo poema único, y mucho debe haber de cierto en ello cuando esa percepción se me ha aparecido alguna vez en el proceso mismo de organización de los materiales. Creo, pues, en esa física del libro, una física no distinta a la que rige el propio poema, en ocasiones llevada por una numerología que, como otros elementos «interiores» del poema y del libro, pertenece a lo más profundo del mysterium del conocimiento poético. Pero esos datos y claves no son el poema: son una trama invisible. El designio último de este proceder constructivo es, me parece, un sueño de unidad, el deseo de la unificación (Díaz, 1995: 5).

La presencia en la mitad del poemario de «En el centro de un círculo de islas», que da nombre al conjunto, viene a confirmar la importancia de la construcción casi arquitectónica a la que alude el poeta, así como el vínculo entre la física del libro y el «mysterium del conocimiento poético» que es esa «experiencia de lo sagrado», ese «sentimiento litúrgico», esa «ceremonia» antes evocados a propósito de los pintores. El poema que se sitúa en el centro evoca la llegada del yo poético a la isla de Delos, meta de su peregrinación. Aunque esta isla se sitúa en el centro del conjunto de las Cícladas, cuyo significado en griego es círculo, la relación de esa isla con el centro supera las consideraciones meramente geográficas. Como es bien sabido, Delos fue en la Antigüedad un lugar 
de peregrinación por la presencia en su seno del santuario de Apolo, dios tradicionalmente asociado con el astro solar, con la verdad y la armonía, elementos que figuran en dicho poema como en otros del poemario, contribuyendo a la profunda unidad del mismo.

Ese centro geográfico pasa a ser, pues, un centro espiritual al que el yo poético acude para encontrarse a sí mismo, en búsqueda de su propio ser, como se puede deducir de los versos «Delos, fúlgida y leve, la belleza que cifras / y nos cifra» (Sánchez Robayna, 2007: 38). Al «tratar de encontrar respuesta a su propia existencia» (Peinado Elliot, 2011: 60), el poeta parece aproximarse al misterio del origen de la existencia y del universo. Como lo subraya Carlos Peinado Elliot en un ensayo sobre el poemario La sombra y la apariencia en el que el poeta canario incluye En el centro de un círculo de islas,

En el centro de un círculo de islas, en el que el poeta se dirige a Delos, manifestándose en la travesía este co-pertenecerse entre el peregrino y el centro sagrado. La barca avanza "como imantada a un punto, su fin fiel", los rostros muestran la fidelidad, el ofrecimiento y la entrega; pero Delos, igualmente avanza hacia los navegantes y viene hacia su encuentro (mostrando el rasgo personal de lo divino, que es siempre animado y toma la iniciativa, según la caracterización ya clásica de Rudolf Otto). Se trata, por tanto, de un diálogo, de una entrega mutua, en la cual se va a "alcanzar el borde, el ciego origen / de toda luz, la luz indestructible". El libro se concibe como un continuo y reiterado regreso al centro (Peinado Elliot, 2011: $60)$.

Los poemas que preceden «En el centro de un círculo de islas» parecen remitir a la peregrinación, el viaje físico del yo poético a Delos, mientras que los siete siguientes aluden a su estancia. Contribuye a esta interpretación el hecho de que figure al principio del poemario «Llega a un lugar de encuentro con el comienzo de lo terrible» (Sánchez Robayna, 2007: 17), en el que se hace referencia a Sunión, puerto situado a unos 60 kilómetros de Atenas y punto de partida de la navegación a Delos. De la misma forma, los poemas que vienen a continuación del poema central parecen seguir teniendo como marco esa misma isla, como permiten afirmar las referencias al lago de Ierí Limni en el noveno poema y «Al dios de Delos» (Sánchez Robayna, 2007: 51) en el undécimo, aunque en éste el uso de «allí» da a entender que el yo poético ya no se sitúa en esa isla. Conviene admitir, sin embargo, que excepto por estas referencias, ningún otro elemento nos permite afirmar que el poemario se organiza a partir de un antes y un después a esa llegada al centro. Se podría incluso llegar a afirmar que es la situación física del poema antes o después de este centro la que viene a condicionar la interpretación de los poemas como evocación de un antes o un después al viaje.

El juego en cuanto al uso de los tiempos viene incluso a manifestar lo contrario: si en los tres primeros poemas se utiliza el presente, que puede ser presente de narración como en «Llega a un lugar de encuentro con el comienzo de lo terrible» y presente de verdad general, aparece en el cuarto, titulado «Septiembre, el lugar» (Sánchez Robayna, 2007: 27), el futuro de indicativo, con el que el yo poético remite a las acciones que hará ese 'tú' que no parece sino su alter ego: «Caminarás», «tal vez una esperanza, / te será dada» y «caerás» que se puede explicar, como lo vamos a analizar más detenidamente, por la concepción del tiempo como circularidad. Este uso del futuro contrasta con el 
pretérito indefinido de las dos composiciones siguientes: «De una danza» e «Hydra, septiembre» antes de volver al presente con el poema «En el centro de un círculo de islas». Cabe subrayar, sin embargo, que en este poema tripartito, se emplea el imperfecto de indicativo en la primera parte, creando así un desfase temporal entre las estrofas iniciales que remiten a la navegación («La barca avanzaba», «los cuerpos que avanzaban y avanzaban» (Sánchez Robayna, 2007: 37)) y el presente de la llegada a Delos y la experiencia de lo sagrado que conlleva en las estrofas siguientes de la primera parte. Este presente se mantiene en la tercera parte como si la llegada a Delos supusiera el paso de una temporalidad marcada por el pasado a un presente de eternidad. Es lo que parece confirmar el uso de este tiempo en los siguientes poemas, antes de volver a una alternancia entre pasado y presente en los cuatro últimos poemas. Este uso de los tiempos viene a romper con la impresión inicial de organización del poemario en dos partes que coincidiera con un antes y un después a la peregrinación del poeta a la isla de Delos. Si ésta no deja de constituir la meta del viaje, la alternancia en cuanto al uso del presente, pasado y futuro muestra que más que la evocación de una peregrinación efectiva, aunque ésta sirva de base, se trata de un doble viaje: a la vez físico, que se inscribe en una linealidad temporal, y conceptual, abstracto que rompe con esta y al que remiten los dibujos de Broto, como lo hemos evocado.

El poemario no es sino la reconstrucción mental de este viaje que posiblemente hizo el poeta a Delos: aunque algunos poemas parecen haberse escrito durante esta peregrinación, otros parecen haberlo sido desde el recuerdo de esa experiencia, como es el caso de los poemas en los que se emplea el pasado, reforzado por la presencia del adverbio «allí» (Sánchez Robayna, 2007: 51). No se limita esa construcción conceptual a la mera memoria. El poeta remite a esa peregrinación al centro desde distintas perspectivas: desde el hic et nunc, desde el prisma de la memoria o el de la proyección en el caso de los futuros, que no dejan de inscribir el poemario en la linealidad del tiempo pero también, y sobre todo, desde una perspectiva fuera del tiempo y del espacio, anterior no sólo al viaje, sino a la existencia del poeta e incluso del universo. Esto puede explicarse por el «copertenecerse entre el viajero y el centro sagrado» al que aludía Carlos Peinado Elliot en la cita anteriormente evocada. Resulta interesante, sin embargo, ver que no se da un cambio de perspectiva entre los poemas anteriores y los posteriores a esa llegada al «ciego origen de la luz» (Sánchez Robayna, 2007: 38) del poema central. Como lo hemos esbozado, no se aprecia un paso del pretérito indefenido o del presente de narración al presente de verdad general a partir del «En el centro de un círculo de islas», lo que crearía un antes y un después a esa llegada al centro. El paso constante de uno a otro, sea en los poemas antes, sea después de este eje, viene a cuestionar esa aparente estructura simétrica que es la que parece tener el poemario si consideramos, lo hemos matizado ya, que éste se construye siguiendo el recorrido de la peregrinación del poeta. El poemario parece más bien construirse a partir de una superposición de círculos que materializan ese «continuo y reiterado regreso al centro» que destacaba Carlos Peinado Elliot y que construye la «trama invisible» a la que aludía Andrés Sánchez Robayna a la hora de evocar la importancia de la construcción arquitectónica en la construcción de sus obras. 
Es lo que vienen a reforzar los dibujos con los ecos entre unos y otros en el conjunto del poemario, como, por ejemplo, entre los motivos en formas de espirales como en el primer y antepenúltimo, las formales circulares como entre el segundo y tercero, las formas orgánicas, en el quinto y séptimo, que enmarcan el poema central y por fin, las que podrían ser plasmaciones del movimiento, como en el caso de los dibujos que preceden a «Una danza» $\mathrm{y}$ «Al dios de Delos». Estas correspondencias entre unos y otros pueden aludir a esa trama invisible a partir de la cual se construye En el centro de un círculo de islas, como si los dibujos desvelaran la verdadera estructura, por debajo de la aparente construcción simétrica entre un antes y un después a «En el centro de un círculo de islas» que ya no resistía a un análisis más detallado del conjunto, como lo hemos intentado demostrar. El paso continuo de los textos a las imágenes a lo largo de la lectura del poemario puede remitir también a esta circularidad del poemario.

Esa circularidad estructural parece materializar pues ese «cero, origen, turbión o remolino, interminable círculo» que se puede leer en el primer poema en prosa del conjunto y que no es sino ese «ojo del tiempo» cuya obra es la existencia humana («somos tu obra»). Lo circular puede, en efecto, remitir al ciclo de la vida: desde el nacimiento hasta la muerte que es evocada como una vuelta a la «entraña del astro». La asociación entre ciclo de la vida humana y astro solar puede explicar la confusión en el poema «Hydra, septiembre»: «El cuerpo entró en las aguas. Luego / lento surgió del mar. / Solar su luz hinchó la luz, las aguas / de sacra sobriedad.» (Sánchez Robayna, 2007: $35)$.

Aunque este cuerpo pueda ser el del yo poético entrando en las aguas o una referencia al anochecer y amanecer, cuando el sol parece entrar o salir del mar, la ambigüedad viene a remarcar esta concepción de la vida como ciclo. De hecho, es interesante ver la importancia de esa concepción del tiempo. Si el paso del ser humano por la tierra se puede concebir dentro de la linealidad temporal, como es la que parece predominar cuando el poeta comprueba, por ejemplo, los estragos del tiempo en las ruinas de los tiempos griegos («isabes qué son estas columnas rotas / que rodaron al mar por la ladera / y hoy yacen bajo el agua, luz que beben / los celajes del tiempo devastado?» (Sánchez Robayna, 2007: 35)), lo es en la mayoría de los casos dentro de una concepción circular. A diferencia de la primera, esta permite ver la existencia física solo como una faceta, una etapa de un ciclo que la sobrepasa aunque sea desde la inmaterialidad. Parece estructurarse la obra a partir de esta concepción cíclica del tiempo: si el poemario empieza con la evocación, en «Llega a un lugar de encuentro con el comienzo de lo terrible», de la luz matinal, vemos como se evoca el anochecer cuatro poemas después, lo que viene confirmado por la puesta del sol en el poema que hemos citado. Este mismo poema alude también, como se puede apreciar en esa cita, a cómo vuelve a amanecer, abriendo así otro ciclo en el que se insiste en «la luz cegadora del sol» (Sánchez Robayna, 2007: 45). Es interesante subrayar que no aparece ninguna referencia al anochecer en los poemas siguientes. En cambio, son numerosas, incluso más que en los poemas anteriores a «En el centro de un círculo de islas», las referencias a la muerte. Esta sustitución del anochecer por la muerte dentro de la evocación del ciclo solar viene a reforzar a ese paralelismo entre éste y la existencia humana. 
Pero más allá de esta evocación al ciclo natural, la omnipresencia de esta circularidad, tanto al nivel temático como estructural, nos parece significativa de la especularidad del conjunto de la obra de la que participan, en primer lugar, las imágenes. Lo ilustran los versos finales de «Díptico de la piedra» cuando el poeta evoca a próposito de una piedra que contempla que, «En la mano / mirabas el origen / nacer en la mirada» (Sánchez Robayna, 2007: 53). Amén de los ecos antes demostrados entre imagen y poema tanto por la materialización de la dualidad visible/invisible como por el intento de unificación a través de la materia, el último dibujo parece ser una clara referencia a la escritura. Además de ser el único en el que no se pueda apreciar parecidos formales con otro, -lo cual es lógico tratándose de un número impar de ilustraciones-, la forma allí plasmada recuerda claramente la de un signo lingüístico, que sea un ideograma o una letra del alfabeto árabe. Si puede parecer rara, en semejante contexto, la presencia de un signo lingüístico que no pertenezca al alfabeto griego, puede tener una explicación por la importancia concedida a la materia: la letra se hace, más que en los alfabetos occidentales, dibujo y no remite, si uno no conoce su significado, a ningún elemento exterior al signo, reforzando así la estructura especular del conjunto de la obra

Más que la evocación de una peregrinación del yo poético a la isla de Delos, En el centro de un círculo de islas nos parece ser más bien la de un poeta a la hora de plasmar mediante la escritura lo sagrado, lo absoluto, lo eterno que dice haber experimentado allí. Además del intento de transmitirlo mediante la materialidad de los signos lingüísticos, el poeta recurre a la de los dibujos de José Manuel Broto que hace visible de manera más inmediata que la escritura lo invisible de esa experiencia. Más allá de esta facultad de la imagen de no sólo hacer visible sino ser visible, ésta parece ser un soporte más duradero que el de la palabra a la hora de aferrarse a lo concreto, lo material, que por muy efímero que sea, parece ser una respuesta a la fugacidad de la vida tal y como se evoca en numerosas ocasiones en el poemario. Parece, el último poema en prosa del poemario dedicado a la «imagen» del amuleto, significativo de la relación del poeta con los dibujos de José Manuel Broto a la hora de concebir la obra:

Y DE QUÉ mal habrías de protegerme tú, imagen, amuleto, idolillo del tiempo, sino del ácido del tiempo [...] Tan sólo tu figura escueta y blanca, puro mármol desnudo que no viene de los pozos del tiempo, del fondo de la tumba donde son siempre hallados tus ancestros, sino de manos fieles hasta unas manos cóncavas. El tiempo borró el polvo de azurita o hematita. Protégeme del ácido del tiempo, ya que no de la tumba, tu oscuridad, tu luz (Sánchez Robayna, 2007: 55).

Aunque esté presente la dimensión temporal en estos dibujos, como lo hemos evocado a propósito del movimiento y de la transformación que se desprenden de ellos, la imagen es ante todo espacio. Sin pretender motivar la teoría que Lessing desarrolla en el Laocoonte, no se puede negar la fuerte dimensión espacial de los dibujos de José Manuel Broto como si se trataran de las islas por las que pasa el yo poético no sólo para acceder, como lo hace en su peregrinación a Delos, a ese absoluto al que aspira sino como trozos de tierra firme en los que poder agarrar esas piedras que son «átomos bullentes de lo eterno» (Sánchez Robayna, 2007: 54). 
El diálogo entre palabra e imagen en En el centro de un círculo de islas

\section{Bibliografía}

BlesA, T. (2010): «La sombra y la apariencia. Andrés Sánchez Robayna» El Cultural, http://elcultural.com/revista/letras/La-sombra-y-la-apariencia/28272 (última consulta, 25-102017).

Broto, J. M. (2006): Broto: El tiempo y el lugar. Zaragoza, Ayuntamiento de Zaragoza.

Collado, G. (2006): «El tiempo y el lugar», en Broto: El tiempo y el lugar. Zaragoza, Ayuntamiento de Zaragoza, pp. 9-16.

DíAz, R.-J. (1995): «La poesía como unificación (Entrevista a Andrés Sánchez Robayna)», Poesía en el Campus, Zaragoza, pp. 4-7.

EusEBio, C. (2015): «Los ojos son el lugar de encuentro entre el espíritu y el mundo», Cuadernos Hispanoamericanos, 780, pp. 50-57.

Fernández Casanova, M. (2005): “'Sentidos que no sé”: el pensamiento poético de Andrés Sánchez Robayna», Revista Hispánica Moderna, Columbia University, 58, 1-2, pp.135-158.

GALA, C. (2014): «Correspondencias, confidencias y contrapuntos: Andrés Sánchez Robayna y Antoni Tàpies», 2014, Bulletin hispanique, 116, pp. 415-438.

MAsoliver Ródenas, J. A. (1985): «La poesía de Andrés Sánchez Robayna en el éxtasis de la materia», Poesía en el campus, 1995, pp.15-18.

Mata Buil, A. (2014): “"Latiendo sobre el ojo que escucha la tinta”», Anuario de Estudios Atlánticos, Las Palmas de Gran Canaria, 60, pp. 721-761

MogA, E. (2012), «La sombra y la apariencia», en http://revistacritica.com/contenidosimpresos/vigilia/la-sombra-y-la-apariencia-de-andres-sanchez-robayna (última consulta, 10-122017).

MuEz, M. (2005): «El pintor Broto inventa un herbario abstracto y lo llama 'Botánica'», El País, https://elpais.com/diario/2005/05/15/paisvasco/1116186009_850215.html (última consulta, 1012-2017).

Peinado Elliot, C. (2011): «La sombra y la apariencia en Andrés Sánchez Robayna», Cuadernos Hispanoamericanos, 727, pp.53-63.

PeYre, Y. (2001): Peinture et poésie. Le dialogue par le livre. París, Gallimard.

RODRÍGUEZ-REFOJO, A. (2006): «Sobre una confidencia del mar griego, precedido de Correspondencias de Andrés Sánchez Robayna y Antoni Tàpies», Letras libres, 60, https://letraslibres.com/mexico-españa/libros/sobre-una-confidencia-del-mar-griego-precedidocorrespondencias-andres-sanchez-robayna-y-antoni-tapies (última consulta, 10-12-2017).

Sabournin, L. (2008): Poésie et illustration. Nancy, Presses universitaires de Nancy, collection du Centre d'Étude des Milieux littéraires.

SÁnchez Robayna, A (2007): En el centro de un círculo de islas. Lanzarote, Fundación César Manrique.

(2008): Deseo, imagen, lugar de la palabra. Barcelona, Galaxia Gutenberg. (2015): Variaciones sobre el vaso de agua. Barcelona, Galaxia Gutenberg. 